\title{
Examining A Decade Of Named Marketing Chairs In The United States
}

Ravindra R. Kamath, (Email: r.kamath@csuohio.edu), Cleveland State University Heidi Hylton Meier, (Email: h.meier@csuohio.edu), Cleveland State University S. R. Rao, Cleveland State University

\begin{abstract}
Named chairs in the academic field of marketing are examined for ten years providing time series and cross-sectional analysis to determine a profile of their personal characteristics and their schools.
\end{abstract}

\section{INTRODUCTION}

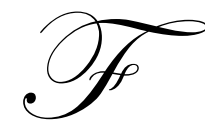

or nearly 150 years, outstanding professors at U.S. universities have been rewarded by receiving the designation of distinguished chair or fellow. The primary purpose for establishing these "named" positions is to provide recognition to faculty members for their accomplishments by giving them additional compensation, funds for travel, and in some disciplines, equipment and labs, and assistance with their research and teaching. Recently, there has been tremendous growth in the number of named chairs in all academic areas, but especially in business disciplines where schools seek to attract and retain qualified faculty members, but university budgets may not provide sufficient resources to do so. Therefore, donations and endowments of sponsors, for whom many times these "titled" professorships are named, are used to supplement the compensation of these faculty members and reward them for their outstanding teaching and or research. In addition, named professorships boost the reputation of the university and promote the image and philanthropy of the donor.

In this study, we analyze the multidimensional characteristics of named chairs in the academic field of marketing over the last ten years. The objective of this examination is to ascertain the characteristic profiles of current named professors in marketing; the characteristics of colleges and universities which provide named chairs to their faculty; and trends that indicate similarities and differences in these profiles over the last decade. This study examines four time periods with the most recent information from 2002-2003 along with past information dating back to the 1994-1995 academic year.

This paper begins with a brief review of the literature on named professorships, followed by a description of the methodology used, and then the findings are presented. A summary of our findings and suggestions for future study makes up the final section.

\section{LITERATURE REVIEW}

Princeton University awarded the first documented named professorship, or chair, at a U. S. university, in 1857 named after Silas Holmes (Leitch, 1978). It was not long after that, that Harvard, Princeton and other institutions started funding endowments to develop other chaired professorships. This has led to the existence of many academic chairs in U.S. universities and rapid growth in the number of these positions over the last several years. Along with the recent growth in these positions, there has also been interest from researchers to examine the establishment of these positions and the details surrounding them. Some of this research includes a study by Murrey and Tosh (1983) in the field of insurance, Fitzpatrick (1986) in the field of nursing, and Bell (1986) in the field of gerontology and geriatrics. 
In business disciplines, Katz (1991) studied 102 named professorships or chairs in the area of entrepreneurship and Metwalli and Tang (2002) examined a broad overview of management professorships in their study of 281 chairs in 1997. There have been several studies in the area of accounting named professorships, starting with Worthington, Waters, and Fields (1989) who provide a composite profile of a "typical" chairholder in accounting; Tang, Forrest and Leach (1990) surveyed administrators of accounting programs to examine the size of the endowment and purpose of the professorship at that school; and Bloom, Fuglister and Meier (1996) surveyed named professors about the nature and mission of their position, examined differences between professorships existing for less than five years and those existing for more than five years, as well as those at public and private universities. Tang (1993) updated Worthington, Waters, and Fields (1989) by providing a profile of 305 accounting chairs in 1992 and Tang and Griffith (1997/1998) provide a more recent profile of 380 accounting chairholders at 166 institutions in 1997. Their results show that despite continued growth in the numbers of these chairholders, the original profile provided by Worthington, Waters, and Fields (1989) had not changed greatly. In the academic areas of finance and marketing, there is only one study each. Metwalli and Tang (2001) provide an overview of the 287 finance professorships that existed in 1999; and Kamath, Meier and Rao (2004) examine 195 marketing chairs in 2002 to determine a profile of the personal characteristics of the named chairs, the characteristics of the schools providing named chairs in marketing and give some recommendations for establishing named positions.

This current study extends the work done by Kamath, Meier and Rao (2004) by examining named chairs in marketing for the ten year period $1994-2003$. This data is analyzed to determine the growth in these positions over that time period and looks at trends, similarities, and changes that may have occurred with regard to these positions.

\section{DATA AND METHODOLOGY}

The Prentice-Hall Company has been publishing "Faculty Directories" for Economics as well as for various business disciplines for almost two decades. These guides, compiled by Professor James Hasselback, contain data provided by over 800 schools. The fields of finance, accounting and marketing have benefited immensely from the useful information contained in these directories. To meet the broadly stated objectives of this paper, we gathered and analyzed pertinent data from four issues of the Hasselback's Marketing Faculty Directory for the academic years: 1994-1995, 1996-1997, 2000-2001, and 2002-2003. While these guides have included the faculty members who teach marketing at U.S. colleges and universities along with faculty from numerous schools outside the U.S., this paper focuses only on the faculty at U.S. institutions.

The data collected for this study were obtained from the faculty guides for individuals that have the designation of a special or named "chair," "professorship," or "fellowship." The personal information for each of these individuals, including their names, ranks, the name of their position, the university where they are currently employed and where they received their highest degree, and their teaching and research interests were recorded. The information provided in the faculty guides is a convenient source of information, but may be limited because the information is reported by the school or department and missing data results if they do not respond.

Other sources were also utilized in this study to extract information regarding other dimensions and attributes of named professors, the institutions employing them and the institutions which educated them. These sources include AACSB International (the Association to Advance Collegiate Schools of Business), Business Week rankings of business schools; the Carnegie Foundation, and the web sites of scores of business schools.

\section{FINDINGS}

\section{Characteristics Of Named Chairs}

According to the 2002-2003 Hasselback Marketing Faculty Directory, there were 195 named professors in the academic field of marketing at colleges and universities in the United States. To further analyze the number of named chairs in marketing, Table 1 describes the general attributes of these professors and provides a summary of the number of these positions over the decade. As noted, in 1994-1995 there were 143 named chairs, revealing a growth 
of nearly $36 \%$ in the number of named professors over the ten year period. A substantial portion of this growth took place between 2000-2001 and 2002-2003 when the number of named chairs in marketing increased by $23 \%$.

In comparison to other academic fields in business, marketing lags comparatively to other areas in the number of named chairs. The 195 named chairs in marketing for 2002-2003 can be compared to the 526 in accounting during 2002-2003 and 375 in finance for the same time period.

Table 1: Named Marketing Chairs: General Attributes

\begin{tabular}{|c|c|c|c|c|c|c|c|c|}
\hline \multirow[t]{2}{*}{ Year } & \multicolumn{2}{|c|}{ 1994-1995 } & \multicolumn{2}{|c|}{ 1996-1997 } & \multicolumn{2}{|c|}{ 2000-2001 } & \multicolumn{2}{|c|}{$2002-2003$} \\
\hline & Number & $\%$ & Number & $\%$ & Number & $\%$ & Number & $\%$ \\
\hline Total Number of Named Chairs & 143 & $100.00 \%$ & 149 & $\begin{array}{c}100.00 \\
\%\end{array}$ & 158 & $100.00 \%$ & 195 & $100.00 \%$ \\
\hline Men holding Named Chairs & 136 & $95.10 \%$ & 139 & $93.29 \%$ & 148 & $93.67 \%$ & 181 & $92.82 \%$ \\
\hline Women holding Named Chairs & 7 & $4.90 \%$ & 10 & $6.71 \%$ & 10 & $6.33 \%$ & 14 & $7.18 \%$ \\
\hline \multicolumn{9}{|l|}{ Academic Rank of Named Chairs: } \\
\hline Full Professors & 132 & $92.31 \%$ & 140 & $93.96 \%$ & 147 & $93.04 \%$ & 172 & $88.21 \%$ \\
\hline Associate Professors & 8 & $5.59 \%$ & 6 & $4.03 \%$ & 10 & $6.33 \%$ & 22 & $11.28 \%$ \\
\hline Assistant Professors & 3 & $2.10 \%$ & 3 & $2.01 \%$ & 0 & $0.00 \%$ & 0 & $0.00 \%$ \\
\hline Emeritus/Others & 0 & $0.00 \%$ & 0 & $0.00 \%$ & 1 & $0.63 \%$ & 1 & $0.51 \%$ \\
\hline \multicolumn{9}{|l|}{ Named Chairs received their highest degree in: } \\
\hline 1940-1949 & 1 & $0.70 \%$ & 1 & $0.67 \%$ & 1 & $0.63 \%$ & 0 & $0.00 \%$ \\
\hline $1950-1959$ & 6 & $4.20 \%$ & 5 & $3.36 \%$ & 3 & $1.90 \%$ & 3 & $1.54 \%$ \\
\hline 1960-1969 & 40 & $27.97 \%$ & 34 & $22.82 \%$ & 31 & $19.62 \%$ & 30 & $15.38 \%$ \\
\hline 1970-1979 & 80 & $55.94 \%$ & 87 & $58.39 \%$ & 83 & $52.53 \%$ & 92 & $47.18 \%$ \\
\hline 1980-1989 & 11 & $7.69 \%$ & 19 & $12.75 \%$ & 34 & $21.52 \%$ & 56 & $28.72 \%$ \\
\hline 1990-1999 & 3 & $2.10 \%$ & 3 & $2.01 \%$ & 3 & $1.90 \%$ & 12 & $6.15 \%$ \\
\hline Not Available & 2 & $1.40 \%$ & 1 & $0.67 \%$ & 3 & $1.90 \%$ & 2 & $1.03 \%$ \\
\hline Mean Year of Graduation & 1971.76 & & 1972.77 & & 1974.9 & & 1976.7 & \\
\hline $\begin{array}{l}\text { Named Chairs who also serve their Institution } \\
\text { in some Administrative Capacity }\end{array}$ & 23 & $16.08 \%$ & 25 & $16.78 \%$ & 36 & $22.78 \%$ & 47 & $24.10 \%$ \\
\hline
\end{tabular}

Table 1 also provides a breakdown by gender of individuals who held these named chairs. In 2002-2003, the majority of named marketing chairs were men $(92.82 \%)$ while in $1994-1995,95.10 \%$ of all named chairs in marketing were held by men. Over the decade, the number of women holding named professorships has doubled, from seven in 1994-1995 to 14 in 2002-2003 but the ratio of men to women was still nearly 13:1 with women only currently holding $7.18 \%$ of all named marketing chairs.

The Faculty Gender Information contained in the AACSB International 2001-2002 salary survey indicates that women constitute 13\%, 23.5\%, and 31.3\% of the ranks of Professor, Associate Professor and Assistant Professor, respectively. Additionally, according to the U.S. Department of Education Statistics (2001) women received 49.53\% of undergraduate degrees, $39.79 \%$ of Masters' degrees, and 31.94\% of Doctoral degrees in business in 1999-2000. These two sets of statistics would suggest that in coming years the percentage of women holding named professorships in business should rise.

Information about the academic ranks of these individuals holding named chairs in marketing is also provided in Table 1. In 2002-2003, about $88 \%$ of the named chairs held the rank of full professor while only $11 \%$ held the rank of associate professor. Interestingly, there are no individuals at the rank of assistant professor who are named chairs and only one retired educator who is still recognized by their university as a named chair in marketing. 
Over the decade, full professors have been more likely to have been rewarded with a named position than individuals at any other academic rank. It is only more recently that there has been a slight increase in the number of associate professors receiving this honor. This may be because universities have begun to realize that it is important to retain their talented junior faculty members and this may be one way to accomplish that goal.

We have also included information in Table 1 about when these individuals received their highest degrees. According to this data, about $47 \%$ of all named marketing chairs in 2002-2003 received their highest degrees between 1970 and 1979 and another $28 \%$ received their degrees between 1980 and 1989. It is interesting to note that over the ten year period, the majority of named chairs in marketing have consistently received their highest degrees during the 1970s. The findings show that nearly $93 \%$ of named chairs in marketing received their highest degrees more than 15 years ago indicating that the majority of these individuals have well established careers and are possibly approaching retirement in the next ten years. This is further highlighted by information on Table 1 showing the mean year that named chairs graduated with their highest degrees. For professors listed in the 1994-1995 guide, the mean year of graduation was 1971.7 and for those listed in the 2002-2003 guide, the mean year of graduation was 1976.7. Over that ten year period, the average year in which these named professors received their degrees has only increased by 5 years.

Also in Table 1 is the number of named marketing chairs who, in addition to their named chair, held an administrative position at their university. The percentage of named chairs who also had administrative responsibilities has grown only slightly from $16 \%$ in1994-1995 to $24 \%$ in 2002-2003.

Table 2: Teaching Interests Of Named Marketing Chairs

\begin{tabular}{|c|c|c|c|c|c|c|c|c|}
\hline \multirow[t]{2}{*}{ Year } & \multicolumn{2}{|c|}{ 1994-1995 } & \multicolumn{2}{|c|}{ 1996-1997 } & \multicolumn{2}{|c|}{ 2000-2001 } & \multicolumn{2}{|c|}{$2002-2003$} \\
\hline & Number & $\begin{array}{c}\% \\
\text { of } 95^{\mathrm{a}}\end{array}$ & Number & $\begin{array}{c}\% \\
\text { of } 108^{a}\end{array}$ & Number & $\begin{array}{c}\% \\
\text { of } 116^{\mathrm{a}}\end{array}$ & Number & $\begin{array}{c}\% \\
\text { of } 121\end{array}$ \\
\hline 1 - Marketing Management & 36 & $37.89 \%$ & 41 & $37.96 \%$ & 37 & $31.90 \%$ & 46 & $38.02 \%$ \\
\hline 2 - Marketing Strategy & 31 & $32.63 \%$ & 36 & $33.33 \%$ & 43 & $37.07 \%$ & 52 & $42.98 \%$ \\
\hline 3 - Promotion/Sales Management & 22 & $23.16 \%$ & 24 & $22.22 \%$ & 25 & $21.55 \%$ & 28 & $23.14 \%$ \\
\hline 4 - Services Marketing & 3 & $3.16 \%$ & 6 & $5.56 \%$ & 8 & $6.90 \%$ & 10 & $8.26 \%$ \\
\hline 5 - Consumer Behavior & 21 & $22.11 \%$ & 25 & $23.15 \%$ & 28 & $24.14 \%$ & 31 & $25.62 \%$ \\
\hline 6 - Channels of Distribution/ Retailing & 13 & $13.68 \%$ & 12 & $11.11 \%$ & 13 & $11.21 \%$ & 19 & $15.70 \%$ \\
\hline 7 - Purchasing & 0 & $0.00 \%$ & 1 & $0.93 \%$ & 2 & $1.72 \%$ & 5 & $4.13 \%$ \\
\hline $\begin{array}{l}8 \text { - International/ Multinational/ Global } \\
\text { Marketing }\end{array}$ & 9 & $9.47 \%$ & 10 & $9.26 \%$ & 13 & $11.21 \%$ & 16 & $13.22 \%$ \\
\hline 9 - Marketing Research & 28 & $29.47 \%$ & 31 & $28.70 \%$ & 33 & $28.45 \%$ & 44 & $36.36 \%$ \\
\hline Professors Reporting Teaching Interests & 95 & $100.00 \%$ & 108 & $100.00 \%$ & 116 & $100.00 \%$ & 121 & $100.00 \%$ \\
\hline Teaching Interests Not Reported For & 48 & & 41 & & 42 & & 51 & \\
\hline
\end{tabular}

${ }^{a}$ Percentages are of the number of professors for whom the teaching interests are reported. The total \% exceeds $100 \%$ because of the multiple areas of interest.

Two important aspects of academic careers are research and teaching interests and the contributions in those areas. Accordingly, to develop a profile of named chairs in marketing, we direct our attention to the teaching and research interests of these individuals. Hasselback provides nine areas of teaching specialties for marketing faculty which includes marketing management, marketing strategy, promotions/sale management, services marketing, consumer behavior, channels of distribution/retailing, purchasing, international and marketing research. Table 2 tabulates this information for each of the four guides in this study. For named chairs in marketing, two areas, marketing strategy and marketing management were reported to be the most popular teaching areas over the ten year period with marketing strategy cited most and marketing management second for 2000-2001 and 2002-2003, while in 1994-1995 and 1996-1997, marketing management was cited as first and marketing strategy as second. This represents a shift during that time period from marketing management to marketing strategy and may be an indication for the future. Also during that time period, the third most cited area for teaching has remained to be marketing research. 
Table 3: Research Interests Of Named Chairs of Marketing a, b

\begin{tabular}{|c|c|c|c|c|}
\hline & 1994-1995 & 1996-1997 & $2000-2001$ & $2002-2003$ \\
\hline A - Product Management & (4) 16 & (1) 21 & (3) 19 & (5) 19 \\
\hline B - Brand Management & 7 & 9 & 9 & 12 \\
\hline C - Pricing Decisions & (11) 10 & (9) 12 & (11) 10 & (11) 15 \\
\hline D - Small Bus/ Entrepreneurship & 5 & 5 & 5 & 6 \\
\hline 1. Marketing Management & 38 & 47 & 43 & 52 \\
\hline E-Segmentation & (6) 12 & (6) 15 & (8) 13 & (8) 17 \\
\hline F - Product Positioning & (6) 12 & (5) 17 & (6) 15 & (3) 22 \\
\hline G - Planning/Implementation/Cnt & (6) 12 & (8) 13 & (6) 15 & (5) 19 \\
\hline * - New Product Development & 1 & 4 & 7 & 8 \\
\hline$\&$ - Business to Business Marketing & 1 & 2 & 3 & 4 \\
\hline 2. Marketing Strategy & 38 & 51 & 53 & 70 \\
\hline $\mathrm{H}$ - Advertising & (2) 17 & (2) 20 & (3) 19 & (4) 21 \\
\hline I - Sales Promotion & 5 & 3 & 3 & 10 \\
\hline $\mathrm{J}$ - Direct Marketing & 5 & 7 & 6 & 7 \\
\hline K - Personal Selling & (11) 10 & (11) 11 & (8) 13 & (10) 16 \\
\hline 3. Promotion/Sales Management & 37 & 41 & 41 & 54 \\
\hline L - Professional Services & 2 & 5 & 7 & 10 \\
\hline 4. Services Marketing & 2 & 5 & 7 & 10 \\
\hline M - Demographics & 4 & 4 & 3 & 5 \\
\hline $\mathrm{N}$ - Consumer Psychology & (4) 16 & (2) 20 & (1) 23 & (1) 28 \\
\hline $\mathrm{O}$ - Information Processing & 7 & 9 & (11) 10 & (12) 14 \\
\hline P - Values \& Life Styles & 7 & 6 & 6 & 8 \\
\hline 5. Consumer Behavior & 34 & 39 & 42 & 55 \\
\hline Q - Channels Management & (10) 11 & (11) 11 & (11) 10 & 13 \\
\hline $\mathrm{R}$ - Logistics & 4 & 5 & 4 & 8 \\
\hline S - Fashion Merchandising & 2 & 2 & 3 & 3 \\
\hline $\mathrm{T}$ - Transportation & 4 & 4 & 4 & 7 \\
\hline 6. Channels of Distribution/Retailing & 21 & 22 & 21 & 31 \\
\hline $\mathrm{U}$ - Purchasing/Materials Mgt & 1 & 2 & 2 & 5 \\
\hline 7. Purchasing & 1 & 2 & 2 & 5 \\
\hline V - Intl Marketing Strategy & (6) 12 & (9) 12 & (8) 13 & (8) 17 \\
\hline W - Intl Marketing Management & 8 & 8 & 9 & 11 \\
\hline X - Intl Comparative Marketing & 1 & 2 & 4 & 6 \\
\hline 8. International/Multinational/Global Marketing & 21 & 22 & 26 & 34 \\
\hline Y - Research Design & (1) 18 & (4) 19 & (2) 20 & (2) 24 \\
\hline Z - Survey Research & (2) 17 & (6) 15 & (5) 16 & (7) 18 \\
\hline 9. Marketing Research & 35 & 34 & 36 & 42 \\
\hline Research interests reported for & 84 & 100 & 108 & 133 \\
\hline No research interests reported for & 59 & 49 & 50 & 59 \\
\hline
\end{tabular}

${ }^{a}$ The headings of the research areas are adopted from the Marketing Faculty Directory 2002-2003, compiled by James R. Hasselback

${ }^{\mathrm{b}}$ The tabulated figures are the numbers of named professors interested in each area/sub-area of research. Numbers in parenthesis report the first 8 ranks in each academic year of the directory publication 
Table 3 provides information about the research interests of named chairs in marketing. Hasselback provides a similar framework for research as for teaching, but presents a more detailed breakdown within each major category. For example, under the major area of marketing management, professors can choose from five subgroups including segmentation, product positioning, planning, new product development, and business to business marketing. According to the information in this table, the overall subject of marketing strategy is cited by the largest number of named marketing chairs as their major research preference since 1996-1997, and it is tied with marketing management in 1994-1995. The second most preferred research area has shifted from marketing management to most recently, consumer behavior.

To examine these subgroups in more detail, we have included parenthetical rankings to reveal the most cited research interests. In these rankings we see a similar shift towards consumer psychology from more traditional areas of marketing like product management (1996-1997) and research design (1994-1995).

\section{Schools Which Graduated The Named Chairs}

A listing of the schools which graduated the most named marketing chairs is presented in Table 4. When examining the four different panels of this table, it becomes apparent that there are significant concentrations of schools that have produced named marketing chairs. Northwestern has emerged as a clear leader by graduating 13, or more than $6 \%$ of all named marketing chairs in 2002-2003, and they have either solely or jointly held that lead position for the last ten years. The number of their graduates holding named chairs has also increased continually over the years. Purdue, Stanford, and Indiana have all been ranked in the top three positions over the ten year period and Michigan State, tied for first in 1994-1995 and 1996-1997, moved down to fourth place in 2000-2001 and 20022003, but has still graduated eight named chairs in marketing. In the listing for 2002-2003, a total of 24 universities have graduated $138(70.77 \%)$ of all named marketing chairs, revealing academic strength in the area of marketing in these schools.

\section{Characteristics Of The Schools}

In this section of the paper, we provide information about the universities that provide named marketing chairs. For each of the four years studied, the universities with the highest concentrations of named professors are listed in Table 5. Table 6 provides a breakdown of these schools by whether they are public or private institutions, as well as their Carnegie Classifications. In Table 7, some additional information about these schools is provided, such as the accreditation status of these schools and media rankings, giving a multidimensional profile not presented in other studies to provide insight into the type of schools that donors are currently supporting to fund distinguished professorships.

The four panels of Table 5 display the names of the schools with more than three named professors in each of the academic years examined. Northwestern leads the group in each of the time periods with a total of $9(6.29 \%)$ named marketing chairs in 1994-1995 and 10 (5.13\%) in 2002-2003 and is tied with the University of Pennsylvania in 1994-1995 and 2002-2003. However the University of Pennsylvania slips to third place in 1996-1997 and seventh in 2000-2001. Over the years, other programs have shifted their position and no other clear leaders surface. Once again, the concentration of schools housing named chairs in marketing appears as in 2002-2003, 28 schools housed 132, that is over $67 \%$ of all named marketing chairs in the U.S. 
Table 4: Schools Which Graduated The Most Named Marketing Chairs

Panel A: Named Chairs in Marketing, 1994-1995

\begin{tabular}{|c|c|c|c|c|}
\hline & Schools Bestowing the Highest Degrees to Named Chairs & How Many & $\%$ of 143 & Cumulative \% \\
\hline 1 & Michigan State, Northwestern, Stanford & 7 each & $4.90 \%$ & $14.69 \%$ \\
\hline 2 & Purdue & 6 & $4.20 \%$ & $18.88 \%$ \\
\hline 3 & $\begin{array}{l}\text { Florida, Harvard, Illinois, Indiana, North Carolina, Ohio State, } \\
\text { Pennsylvania }\end{array}$ & 5 each & $3.50 \%$ & $43.36 \%$ \\
\hline 4 & Arkansas, Minnesota, MIT & 4 each & $2.80 \%$ & $51.57 \%$ \\
\hline 5 & $\begin{array}{l}\text { Carnegie Mellon, Columbia, Kent State, Michigan, Penn State, } \\
\text { Rochester, UCLA }\end{array}$ & 3 each & $2.10 \%$ & $66.43 \%$ \\
\hline & Total Named Chairs from 21 Schools & 95 & $66.43 \%$ & $66.43 \%$ \\
\hline
\end{tabular}

Panel B: Named Chairs in Marketing, 1996-1997

\begin{tabular}{|c|l|c|c|c|}
\hline & Schools Bestowing the Highest Degrees to Named Chairs & How Many & \% of 149 & Cumulative \% \\
\hline 1 & Florida, Michigan State, Northwestern, Purdue, Stanford & 7 each & $4.70 \%$ & $23.49 \%$ \\
\hline 2 & Illinois, Minnesota, North Carolina, Pennsylvania & 5 each & $3.36 \%$ & $36.91 \%$ \\
\hline 3 & $\begin{array}{l}\text { Arkansas, Carnegie Mellon, Harvard, Indiana, Michigan, MIT, } \\
\text { Ohio State, Oregon, UCLA }\end{array}$ & 4 each & $2.68 \%$ & $61.07 \%$ \\
\hline 4 & Columbia, Kent State, NYU, Rochester & 3 each & $2.01 \%$ & $69.13 \%$ \\
\hline & Total Named Chairs from 22 Schools & $69.13 \%$ & $69.13 \%$ \\
\hline
\end{tabular}

Panel C: Named Chairs in Marketing, 2000-2001

\begin{tabular}{|c|c|c|c|c|}
\hline & Schools Bestowing the Highest Degrees to Named Chairs & How Many & $\%$ of 158 & Cumulative \% \\
\hline 1 & Northwestern & 11 & $6.96 \%$ & $6.96 \%$ \\
\hline 2 & Stanford & 9 & $5.70 \%$ & $12.66 \%$ \\
\hline 3 & Indiana, Michigan, Purdue & 7 each & $4.43 \%$ & $25.95 \%$ \\
\hline 4 & Florida, Illinois, Michigan State & 6 each & $3.80 \%$ & $37.34 \%$ \\
\hline 5 & MIT, North Carolina, Pennsylvania, UCLA & 5 each & $3.16 \%$ & $50.00 \%$ \\
\hline 6 & Arkansas, Texas-A & 4 each & $2.53 \%$ & $55.06 \%$ \\
\hline 7 & $\begin{array}{l}\text { Carnegie Mellon, Chicago, Columbia, Minnesota, Ohio State, } \\
\text { Oregon }\end{array}$ & 3 each & $1.90 \%$ & $66.46 \%$ \\
\hline & Total Named Chairs from 20 Schools & 105 & $66.46 \%$ & $66.46 \%$ \\
\hline
\end{tabular}

Panel D: Named Chairs in Marketing, 2002-2003

\begin{tabular}{|c|c|c|c|c|}
\hline & Schools Bestowing the Highest Degrees to Named Chairs & How Many & $\%$ of 195 & Cumulative \% \\
\hline 1 & Northwestern & 13 & $6.67 \%$ & $6.96 \%$ \\
\hline 2 & Purdue & 10 & $5.13 \%$ & $11.79 \%$ \\
\hline 3 & Indiana, Stanford & 9 each & $4.62 \%$ & $21.03 \%$ \\
\hline 4 & Columbia, Mich St & 8 each & $4.10 \%$ & $29.23 \%$ \\
\hline 5 & Illinois, Michigan & 7 each & $3.59 \%$ & $36.41 \%$ \\
\hline 6 & Alabama, Florida & 6 each & $3.08 \%$ & $42.56 \%$ \\
\hline 7 & Car Mellon, Kentucky, MIT, Penn & 5 each & $2.56 \%$ & $52.82 \%$ \\
\hline 8 & Chicago, N Carol, Ohio St, Texas-Austin, UCLA & 4 each & $2.05 \%$ & $63.08 \%$ \\
\hline 9 & Arkansas, Minnesota, Oregon, Tx-Christian, Tx-Tech & 3 each & $1.54 \%$ & $70.77 \%$ \\
\hline & Total Named Chairs from 24 Schools & 138 & $70.77 \%$ & $70.77 \%$ \\
\hline
\end{tabular}


Table 5: The Concentrations Of Named Chairs By Schools Panel A: Named Chairs in Marketing, 1994-1995

\begin{tabular}{|c|c|c|c|c|}
\hline & Schools Where the Named Chairs Were & How & $\%$ of 143 & Cumulative $\%$ \\
\hline 1 & Northwestern, Pennsylvania & 9 each & $6.29 \%$ & $12.59 \%$ \\
\hline 2 & Texas & 7 & $4.90 \%$ & $17.48 \%$ \\
\hline 3 & Virginia & 6 & $4.20 \%$ & $21.68 \%$ \\
\hline 4 & Cornell, Harvard, Michigan & 4 each & $2.80 \%$ & $30.07 \%$ \\
\hline 5 & $\begin{array}{l}\text { Chicago, Minnesota, Nebraska, Oklahoma State, South Calif, } \\
\text { Wisconsin }\end{array}$ & 3 each & $2.10 \%$ & $42.66 \%$ \\
\hline & Total Named Chairs from 13 Schools & 61 & $42.66 \%$ & $42.66 \%$ \\
\hline
\end{tabular}

Panel B: Named Chairs in Marketing, 1996-1997

\begin{tabular}{|c|c|c|c|c|}
\hline & Schools Where the Named Chairs Were & How Many & $\%$ of 149 & Cumulative \% \\
\hline 1 & Northwestern, Texas & 9 each & $6.04 \%$ & $12.08 \%$ \\
\hline 2 & Penn State, Virginia & 6 each & $4.03 \%$ & $20.13 \%$ \\
\hline 3 & Pennsylvania & 5 & $3.36 \%$ & $23.49 \%$ \\
\hline 4 & Cornell, Harvard, Minnesota, Oklahoma State & 4 each & $2.68 \%$ & $34.23 \%$ \\
\hline 5 & Georgia, Michigan, Nebraska, South Calif, Wisconsin & 3 each & $2.01 \%$ & $44.30 \%$ \\
\hline & Total Named Chairs from 14 Schools & 66 & $44.30 \%$ & $44.30 \%$ \\
\hline
\end{tabular}

Panel C: Named Chairs in Marketing, 2000-2001

\begin{tabular}{|c|c|c|c|c|}
\hline & Schools Where the Named Chairs Were & How Many & $\%$ of 158 & Cumulative \% \\
\hline 1 & Northwestern & 9 & $5.70 \%$ & $5.70 \%$ \\
\hline 2 & Texas & 8 & $5.06 \%$ & $10.76 \%$ \\
\hline 3 & Penn State & 7 & $4.43 \%$ & $15.19 \%$ \\
\hline 4 & Harvard, Michigan & 6 each & $3.80 \%$ & $22.78 \%$ \\
\hline 5 & Minnesota & 5 & $3.16 \%$ & $25.95 \%$ \\
\hline 6 & Alabama, Georgia, Oklahoma St, So Calif, Virginia & 4 each & $2.53 \%$ & $38.61 \%$ \\
\hline 7 & $\begin{array}{l}\text { Chicago, Cornell, Florida, Louisiana St, MIT, Nebraska, Ohio State, } \\
\text { Pennsylvania, Virg Tech, Wash Univ }\end{array}$ & 3 each & $1.90 \%$ & $57.59 \%$ \\
\hline & Total Named Chairs from 21 Schools & 91 & $57.59 \%$ & $57.59 \%$ \\
\hline
\end{tabular}

Panel D: Named Chairs in Marketing, 2002-2003

\begin{tabular}{|c|c|c|c|c|}
\hline & Schools Where the Named Chairs Were & How Many & $\%$ of 195 & Cumulative \% \\
\hline 1 & Northwestern, Pennsylvania & 10 each & $5.13 \%$ & $10.26 \%$ \\
\hline 2 & Texas-Austin & 8 & $4.10 \%$ & $14.36 \%$ \\
\hline 3 & Kentucky, Tenn-Chattan & 7 each & $3.59 \%$ & $21.54 \%$ \\
\hline 4 & Penn St, Tx-Tech, Virginia & 6 each & $3.08 \%$ & $30.77 \%$ \\
\hline 5 & Columbia, Harvard, Michigan & 5 each & $2.56 \%$ & $38.46 \%$ \\
\hline 6 & Alabama, Arkansas, Georgia, Iowa, Ohio St, So Calif, & 4 each & $2.05 \%$ & $50.77 \%$ \\
\hline 7 & $\begin{array}{l}\text { Baylor, Chicago, Cornell, Florida, Minnesota, MIT, Nebraska, No } \\
\text { Carolina, Oklahoma St, Tx-Christian, Wash Univ }\end{array}$ & 3 each & $1.54 \%$ & $67.69 \%$ \\
\hline & Total Named Chairs from 28 Schools & 132 & $67.69 \%$ & $67.69 \%$ \\
\hline
\end{tabular}


Table 6: School Types and Carnegie Classifications of Institutions Where Named Chairs of Marketing Were Teaching and Where They Received their Highest Degree

\begin{tabular}{|c|c|c|c|c|c|c|c|c|}
\hline \multicolumn{9}{|c|}{ Panel A: Where They Were Teaching } \\
\hline & 1994-1995 & & 1996-1997 & & 2000-2001 & & $2002-2003$ & \\
\hline & Number & $\%$ of 143 & Number & $\%$ of 149 & Number & $\%$ of 158 & Number & $\%$ of 195 \\
\hline State & 82 & $57.34 \%$ & 93 & $62.42 \%$ & 98 & $62.03 \%$ & 117 & $60.00 \%$ \\
\hline Private & 61 & $42.66 \%$ & 56 & $37.58 \%$ & 60 & $37.97 \%$ & 78 & $40.00 \%$ \\
\hline
\end{tabular}

Panel B: Where They Graduated From

\begin{tabular}{|c|c|c|c|c|c|c|c|c|}
\hline & $\mathbf{1 9 9 4 - 1 9 9 5}$ & & $\mathbf{1 9 9 6 - 1 9 9 7}$ & & $\mathbf{2 0 0 0 - 2 0 0 1}$ & & $\mathbf{2 0 0 2 - 2 0 0 3}$ & \\
\hline & Number & $\%$ of 143 & Number & \% of 149 & Number & $\%$ of 158 & Number & $\%$ of 195 \\
\hline State & 89 & $62.24 \%$ & 93 & $62.42 \%$ & 104 & $65.82 \%$ & 131 & $67.18 \%$ \\
\hline Private & 52 & $36.36 \%$ & 54 & $36.24 \%$ & 52 & $32.91 \%$ & 62 & $31.79 \%$ \\
\hline $\begin{array}{c}\text { Not Available } \\
\text { a }\end{array}$ & 2 & 1.4 & 2 & 1.34 & 2 & 1.27 & 2 & 1.03 \\
\hline
\end{tabular}

Panel C: December 2002 Carnegie Classifications of Institutions
\begin{tabular}{|l|c|c|c|c|c|c|c|}
\hline Carnegie Classification b,c & $\mathbf{1}$ & $\mathbf{2}$ & $\mathbf{3}$ & $\mathbf{4}$ & $\mathbf{5}$ & $\mathbf{6 , 7 , \boldsymbol { 9 } 9}$ & N/A \\
\hline $\begin{array}{l}\text { Of Institutions where the 2002-2003 Named Chairs } \\
\text { in Marketing Were Teaching }\end{array}$ & 156 & 16 & 15 & 0 & 3 & 3 & 0 \\
$(80 \%)$ & $(8.21 \%)$ & $(7.69 \%)$ & $(0.00 \%)$ & $(1.54 \%)$ & $(1.54 \%)$ & $(0.00 \%)$ \\
\hline $\begin{array}{l}\text { Of Institutions where the 2002-2003 Named Chairs } \\
\text { in Marketing Received their highest degree }\end{array}$ & 189 & 3 & 1 & 0 & 0 & 0 & 2 \\
$(96.92 \%)$ & $(1.54 \%)$ & $(0.51 \%)$ & $(0.00 \%)$ & $(0.00 \%)$ & $(0.00 \%)$ & $(1.03 \%)$ \\
\hline
\end{tabular}

a. The 'Not Available' classification is used primarily because of the doctoral degrees granted by institutions outside of the United States

b. This study denotes Carnegie Classifications as of December 1, 2002 in the following manner.
1 Doctoral/Research Universities - Extensive
2 Doctoral/Research Universities - Intensive
3 Masters' Colleges and Universities I
$4 \quad$ Masters' Colleges and Universities II
5 Baccalaureate Colleges - Liberal Arts
6. 7 \& 9 Baccalaureate Colleges - General
Baccalaureate/Associate's Colleges
Specialized Institutions
N/A Not classified

c. In Panel C, the percentages denoted in () are of the 195 total

Panel A of Table 6 presents information about the type of school, public or private, where the named chairs in marketing were teaching. According to this table, in 2002-2003, 60\% of all named chairs were teaching at state schools while $40 \%$ were teaching at private universities. Even though the number of named professorships has increased over the last ten years, this distribution of named professors at state and private schools has remained fairly stable. This is also the case when examining Panel B of Table 6, which reveals that $67 \%$ of named chairs of $2002-$ 2003 had received their highest degrees from state universities and 31\% received their highest degrees from private universities. This distribution has fluctuated only slightly over the years, but state schools appear to be expanding their lead by gaining nearly five percentage points over the ten year period.

For the 2002 - 2003 year, Carnegie Classifications as of December 1, 2002 were utilized to classify the schools where the named chairs were teaching and the schools from where they earned their highest degrees. The emerging distributions are exhibited in Panel $\mathrm{C}$ of Table 6. Carnegie Classifications are based on the amount of federal grant money received by a university and the number of degrees they produce at each academic level. Of all named chairs in marketing, $80 \%$ (156) were teaching at a school with a Carnegie Classification of 1, a Doctoral/Research University-Extensive. This classification requires the highest level of federal funding and the highest number of doctoral degrees granted in a broad number of areas over a certain period. The next highest level of 
concentration of named chairs, about $8 \%$, were at schools with a Carnegie Classification of 2 (Doctoral/Research Universities-Intensive) and 7.6\% of named chairs in marketing were at schools with a Carnegie Classification of 3 (Masters Colleges and Universities I).

With respect to the Carnegie Classifications of the schools which granted named chairs in marketing their highest degrees, we find that nearly $97 \%$ received their highest degrees from schools with a Carnegie Classification of 1, a Doctoral/Research University-Extensive. Overwhelmingly, the vast majority of named chairs in marketing had received their degrees from schools with the highest classification and although there is slight diversity in the Carnegie Classifications of the schools where named chairs in marketing were teaching, it too, is minor.

Table 7: Accreditation and Business Week ranking of Schools Where Named Chairs of Marketing Were Teaching

Panel A: Accreditation

\begin{tabular}{|l|l|c|c|}
\hline & \multicolumn{1}{|c|}{ Number } & \multicolumn{1}{|c|}{$\%$} \\
\hline 1 & $\begin{array}{l}\text { Number of named chairs at schools with AACSB Accreditation in } \\
\text { Business in December, 2002 }\end{array}$ & 190 & $97.44 \%(\%$ of 195) \\
\hline
\end{tabular}

Panel B: Named Chairs at schools Where Recruiters Say They Find the Best Graduates with Marketing Skills as Published by Business Week

\begin{tabular}{|c|c|c|c|}
\hline & & Number & $\%$ \\
\hline 1 & $\begin{array}{l}\text { Number of named chairs at schools listed among the Best } 10 \text { for } \\
\text { developing marketing skills in } 2002\end{array}$ & 48 & $24.62 \%(\%$ of 195$)$ \\
\hline 2 & $\begin{array}{l}\text { Number of named chairs at schools listed among the Best } 10 \text { for } \\
\text { developing marketing skills in } 2000\end{array}$ & 37 & $23.42 \%(\%$ of 158$)$ \\
\hline 3 & $\begin{array}{l}\text { Number of named chairs at schools listed among the Best } 10 \text { for } \\
\text { developing marketing skills in } 1996\end{array}$ & 35 & $23.49 \%(\%$ of 149$)$ \\
\hline 4 & $\begin{array}{l}\text { Number of named chairs at schools listed among the Best } 5 \text { for developing } \\
\text { marketing skills in } 1994 *\end{array}$ & 25 & $17.48 \%(\%$ of 143$)$ \\
\hline
\end{tabular}

* Business Week only listed top 5 schools where recruiters said they found the best graduates with marketing skills in 1994

Panel C: Named Chairs at Schools Ranked in the List of Best Business Schools by Business Week

\begin{tabular}{|c|l|c|c|}
\hline & \multicolumn{1}{|l|}{} & Number & \multicolumn{1}{|c|}{ \% } \\
\hline 1 & $\begin{array}{l}\text { Number of named chairs at business schools listed among the } \\
\text { Best top 30 in 2002 }\end{array}$ & 82 & $42.05 \%(\%$ of 195) \\
\hline 2 & $\begin{array}{l}\text { Number of named chairs at business schools listed among the } \\
\text { Best top 30 in 2000 }\end{array}$ & 68 & $43.04 \%(\%$ of 158) \\
\hline 3 & $\begin{array}{l}\text { Number of named chairs at business schools listed among the } \\
\text { Best top 25 in 1996 }\end{array}$ & 57 & $38.26 \%(\%$ of 149$)$ \\
\hline 4 & $\begin{array}{l}\text { Number of named chairs at business schools listed among the } \\
\text { Best top 20 in 1994 }\end{array}$ & 56 & $39.16 \%(\%$ of 143) \\
\hline
\end{tabular}

* Business Week listed the 20 top business schools in 1994, 25 in 1996 and 30 in 2000 and 2002

In Table 7, some other dimensions of the universities that employed named marketing chairs are noted. As illustrated, in 2002, 190 of the named marketing chairs were at schools that had AACSB accreditation in business. This represents more than 97\% of the total named chairs in marketing. On December 1, 2002, 406 business schools, or approximately $28 \%$ of all business schools in the U.S. had AACSB accreditation for their business programs. The large percentage of named chairs at accredited schools attests to the quality of the marketing programs as AACSB accreditation has been established to assure academic quality in business programs. Accredited schools are required to follow certain standards concerning faculty composition and development; curriculum content and evaluation; instructional resources and responsibilities; students; and intellectual contributions. 
Another interesting characteristic found in Table 7 is information about the number of named marketing chairs at schools which have been ranked by Business Week as being the "Best 10" for developing marketing skills and/or ranked in their top 30 business schools. These rankings are highly publicized by the schools and thought to enhance the image of the school in terms of attracting the most qualified faculty, the best students into their programs, and donors willing to contribute funds to the schools.

Panel B of Table 7 shows that in 2002 there were 48, or nearly 25\%, of named chairs in marketing teaching at schools that were ranked as the best for developing marketing skills. This number has nearly doubled over the ten year period when there were 25 or $17 \%$ of named marketing chairs at these schools. In Panel C, there is even a larger concentration of marketing chairs, 82 or more than $42 \%$ in 2002, at schools in which Business Week ranks as their top 30 business schools. This represents an increase from 56, or 46\% from the number reported in 1994.

There is still some debate as to the importance of these rankings. Research by Trieschmann et al. (2000) reports little correlation between media rankings and academic research production while a 'halo effect' is cited by Graham and Diamond (1999) that may enhance the reputations of the academics at those schools explaining some association between the rankings and the number of named chairholders at those schools. Hence, schools perceive benefits from these rankings and their advertising and recruiting materials reflect this accomplishment.

\section{SUMMARY}

This study further advances the research pertaining to named chairs in marketing by providing a multidimensional profile of the characteristics of these professorships and expanding upon the previous literature. We have determined that the current named chair in marketing is most likely a male, full professor who is currently teaching in the area of marketing strategy or marketing management at a doctoral granting university. This individual received his highest degree more than 15 years ago from a well known doctoral granting university and is likely conducting research in the area of marketing strategy.

Based on the data of the last 10 years, we also determined that there are certain schools with high concentrations of named chairs in marketing. For example, of the total 195 named chairs in 2002-2003, 42, or more than $21 \%$, were employed by just five schools and 75 , or more than $38 \%$, were employed by 11 schools. A similar level of concentration is found with regard to the universities that educated these named chairs. Northwestern has consistently educated the most named chairs in marketing. In 2002-2003, just four schools were found to have trained 41 , or $21 \%$, of the 195 named chairs and ten schools had educated 83 , or more than $43 \%$, of the named chairs. A review of the media rankings by Business Week is also provided in this paper to further examine the schools where named chairs in marketing were teaching. We found that currently, more than $24 \%$ of named chairs in marketing were employed by schools considered to be the best for developing marketing skills and more than $42 \%$ were at the top 30 business programs.

In conclusion, it is generally believed that there are many benefits derived by establishing named chairs including improving public relations, highlighting the image of the donor, enhancing recruitment and gaining better access to research facilities. It would appear that universities and donors definitely value these benefits as the number of named chairs in marketing continues to increase and the strong association between housing these named professors and their national rankings continue to exist.

\section{REFERENCES}

1. Accreditation. www.aacsb.edu. December 2002.

2. America's Best Colleges 2003. www.usnews.com, December 2002.

3. Bell, W. G. Endowed Position in Gerontology and geriatrics in Higher Education: Results from a Preliminary Survey. Educational Gerontology, Volume 12, 1986.

4. Bloom, R., J. Fuglister, and H. H. Meier, Trends in Named Professorships in Accounting. Accounting Educators' Journal, Spring, 1996.

5. Carnegie Classifications. www.Carnegiefoundation.edu, December 2002. 
6. $\quad$ Fitzpatrick, J. J. Endowed Chairs in Nursing: Update. Journal of Professional Nursing, May/June 1986.

7. Graham, H. D. and N. Diamond. Academic Departments and the Ratings Game. Chronicle of Higher Education, June 18, 1999.

8. Hasselback, J. R. Marketing Faculty Directory 2002-2003, 2000-2001, 1996-1997, and 1994-1995. Prentice-Hall, Englewood Cliffs, New Jersey, 2002.

9. Kamath, R., Meier, H. H. and S. R. Rao. A Comprehensive Study of Named Marketing Chairs at Colleges and Universities in 2002. Marketing Education Review, Summer 2004.

10. Leitch, A. A Princeton Companion. Princeton Press, Princeton, New Jersey, 1978.

11. Meritt, J. The Best B-Schools Business Week, October 21, 2002.

12. Metwalli, A. M. and R. Y. W. Tang. Finance Chair Professorships in the United States. Journal of Financial Education, Spring 2001.

13. Metwalli, A. M. and R. Y. W. Tang. Management Chair Professorships in the United States. Journal of Education for Business, January/February 2002.

14. Murrey, J. H., Jr. and D. S. Tosh. Chairs of Insurance in American Colleges and Universities. CPCU Journal, June 1983.

15. Tang, R. W. A Profile of Accounting Chair Professorships in 1992. Journal of Education for Business, January/February 1993.

16. Tang, R. W. and D. Griffith. Accounting Chair Professorships in 1997. Journal of Applied Business Research, Winter 1997/1998.

17. Tang, R. W., J. P. Forrest, and D. Leach. Findings from a Survey on Accounting Chair Professorships. Journal of Accounting Education, Fall 1990.

18. Trieschmann, J. S., Dennis, A. R., Northcraft, G. B., and A. W. Niemi, Jr. Serving Multiple Constituencies in Business Schools: MBA Program Versus Research Performance. Academy of Management Journal, December 2001.

19. U.S. Department of Education. Postsecondary Institutions in the United States: Fall 2000 and Degrees and Other Awards Conferred: 1999-2000. U.S. Department of Education, Washington, D.C, 2001.

20. Worthington, J. S., C. L. Waters, and K. T. Fields. A Profile of Chairholders Based on Chair Efficiency Ratios. Accounting Educators' Journal, Summer 1989. 